$\stackrel{W}{N=}$

Global burnals Inc.

$(8)$

GLOBAL JOURNAL OF MEDICAL RESEARCH: C

MICROBIOLOGY AND PATHOLOGY

Volume 21 Issue 1 Version 1.0 Year 2021

Type: Double Blind Peer Reviewed International Research Journal

\title{
Characteristics Shared between Lung Development and Tumorigenesis: Mini Review Article
}

By Josenel Maria Barcelos Marçal, Júlia Iaroseski, Luiz Fillipe Pinto da Silva, Thales Augusto Della Torre Marzarotto, Giulia Righetti Tuppini Vargas, Vitória Morita Fukuoka, Luiza Carolina da Rosa Scherner, Rafael Fabiano Machado Rosa \& Paulo Ricardo Gazzola Zen

Universidade Federal de Ciências da Saúde de Porto Alegre (UFCSPA)

Abstract- Cells with characteristics of embryonic stem cells, and cancer stem cells are at the basis of both embryo development and the cancer process. At the same time, they share signaling pathways, such as the hedgehog, Notch, Wnt, TGF beta, among others. This knowledge is important for understanding the pulmonary regeneration process and for the development of new target therapies.

Keywords: embryogenesis, alveolarization, lung, tumorigenesis, molecular biology, signaling pathways.

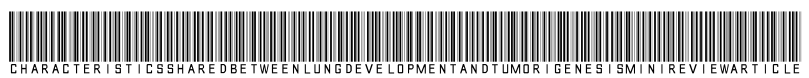

Strictly as per the compliance and regulations of:

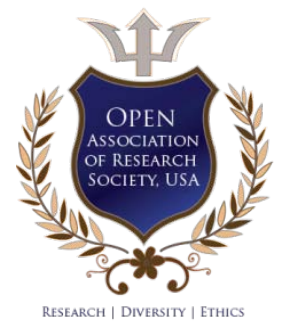

(C) 2021. Josenel Maria Barcelos Marçal, Júlia laroseski, Luiz Fillipe Pinto da Silva, Thales Augusto Della Torre Marzarotto, Giulia Righetti Tuppini Vargas, Vitória Morita Fukuoka, Luiza Carolina da Rosa Scherner, Rafael Fabiano Machado Rosa \& Paulo Ricardo Gazzola Zen. This is a research/review paper, distributed under the terms of the Creative Commons AttributionNoncommercial 3.0 Unported License http://creativecommons.org/licenses/by-nc/3.0/), permitting all non-commercial use, distribution, and reproduction in any medium, provided the original work is properly cited. 


\title{
Characteristics Shared between Lung Development and Tumorigenesis: Mini Review Article
}

\author{
Josenel Maria Barcelos Marçal ${ }^{\alpha}$, Júlia laroseski ${ }^{\sigma}$, Luiz Fillipe Pinto da Silva ${ }^{\rho}$, \\ Thales Augusto Della Torre Marzarotto ${ }^{\omega}$, Giulia Righetti Tuppini Vargas ${ }^{*}$, Vitória Morita Fukuoka ${ }^{\S}$, \\ Luiza Carolina da Rosa Scherner ${ }^{x}$, Rafael Fabiano Machado Rosa ${ }^{\vee} \&$ Paulo Ricardo Gazzola Zen ${ }^{\ominus}$
}

\begin{abstract}
Cells with characteristics of embryonic stem cells, and cancer stem cells are at the basis of both embryo development and the cancer process. At the same time, they share signaling pathways, such as the hedgehog, Notch, Wnt, TGF beta, among others. This knowledge is important for understanding the pulmonary regeneration process and for the development of new target therapies.
\end{abstract}

Keywords: embryogenesis, alveolarization, lung, tumorigenesis, molecular biology, signaling pathways.

\section{INTRODUCTION}

T he understanding of lung development during embryogenesis and the knowledge of several cell populations is essential for regenerative medicine and for the recognition of the cell of origin of lung neoplasms.

Several evidences suggest that the human lung contains a population of characteristic stem cells. This statement is explained by the fact that most patients with small cell lung cancer (CPCP) already have metastases, resistance or refractoriness to chemotherapy treatment at the moment. Likewise, patients with adenocarcinomas that express tyrosine kinase (EGFR) mutations, and who are initially sensitive to therapy, also acquire resistance. (Kobayashi et al. 2005; Pao et al. 2005; Kosaka et al.2006).

Another piece of evidence was the identification of cells from the lateral population, isolated by their ability to efflux the Hoechst dye and which exhibit increased expression of drug transporters, tumor propagation capacity and resistance to multiple chemotherapies (Ho et al. 2007). It was identified that

Corresponding Author $\alpha$ : Graduate Program in Pathology, Department of pathology and forensic medicine, Universidade Federal de Ciências da Saúde de Porto Alegre (UFCSPA), Porto Alegre, Brazil.

e-mail: josenel.copetti@gmail.com

Author $\sigma \rho \omega ¥ \S$ : Graduation in Medicine, UFCSPA, Porto Alegre, RS, Brazil. (ORCID ID:0000-0003-4433-1525).

e-mails: juliaiaroseski@gmail.com, luizfellipeps96@gmail.com, thalesmarzarotto@gmail.com,giu.righetti@gmail.com,

vitoriamf@ufcspa.edu.br

Author x: Master's student of the post-graduate program in pathology, UFCSPS, Porto Alegre, Brazil. e-mail:Icrscherner@gmail.com

Author v: Department of Internal Medicine, Clinical Genetics, UFCSPA and Irmandade Santa Casa de Misericórdia de Porto Alegre (ISCMPA), Porto Alegre, Brazil. e-mail: rfmrosa@gmail.com

Author $\Theta$ : Department of Internal Medicine, Clinical Genetics, (UFCSPA) and Irmandade Santa Casa de Misericórdia de Porto Alegre (ISCMPA), Porto Alegre, Brazil.e-mail: paulozen@ufcspa.edu.br
CD133 positive lung tumor cells formed self-renewing spheres in culture with tumor propagation, when transplanted subcutaneously in immunodeficient mice (Erasmo et al. 2008).

With this review we intend to define the cell types and molecular biology data of the lung in embryogenesis and in the adult lung, drawing points of comparison and trying to correlate with the development of neoplasms.

\section{Pulmonary Development Stages}

The lung has a large internal surface and an airway conduction system with several branches. Conductive airways are formed first, followed by the formation and enlargement of the gas exchange area. Alveolarization is the last stage of the fetal period and continues in the postnatal period.

In the embryonic period, between 4-7 gestational weeks organogenesis occurs. The left and right lungs have their own ring, an external pouch of the anterior intestine (Cardoso and Lu 2006). Each pulmonary bud initiates a repetitive process of growth and branched morphogenesis to form future airways (Schittny and Burri 2008). Epithelial cells are supported by a basement membrane, surrounded by an extracellular matrix that is produced by mesenchymal cells. The components of the extracellular matrix, including the basement membrane, are different in the terminal bud, in the branching points and in the most proximal portions of the bronchial tree, where epithelial differentiation has already started (Schittny and Burri2004). The branching is coordinated by epithelial and mesenchymal cells, growth factors and transcription factors that the cells are producing.

The fetal period includes the pseudoglandular, canalicular and saccular stages. The postnatal lung period comprises the stages of classic and continuous alveolarization, as well as microvascular maturation. As most processes during lung development begin in the proximal area and extend to the periphery, all phases of lung development overlap (Schittny and Burri 2008; Wood and Schittny 2016)

The expression of growth factors, such as fibroblast growth factor 10 (FGF-10), bone morphogenic protein 4 (BMP-4), Sonic Hedgehog (Shh), retinoic acid, Notch and TGF- $\beta$ provide the instructions for 
ramification in the period of morphogenesis. (Cardoso and Lu 2006; Hines and Sun 2014; Schittny and Burri 2008)

The negative feedback mechanism involves signaling by Shh (Sonic hedgehog), its Ptc1 receptor (Patched 1) and transcription factors such as Gli1-3, belonging to the Shh signaling pathway. The Shh pathway acts by inhibiting local expression of Fgf10, preventing branching from occurring indefinitely. The process also depends on complex regulation by signaling pathways of the TgfB (Transforming Growth Factor Beta) family members, Wnt (Wingless- type) and Bmp4 (Bone Morphogenetic Protein 4, from the Tgf Beta family) (Park 1998; Rock and Hogan 2011; Katton and Morrisey 2014).

The Fgf (fibroblast Growth Factor) signaling pathway is activated by localized expression of Fgf10 in the mesoderm and its receptor Fgfr2 in the endoderm. This signaling induces branching, and Fgf10 stimulates the proliferation of epithelial cells. (Rock and Hogan 2011; Katton and Morrisey 2014).

Around the 10th gestational week, respiratory movements begin that cause additional stretching of the fetal lung tissue (Koos and Rajace2014). These stimuli positively regulate the release of serotonin, promoting epithelial differentiation (Pan et al 2006).

A continuous layer of positive cells for a smooth muscle actin begins to form around the future proximal airways, becoming discontinuous distally in the bronchial tree and ending in front of the terminal buds. These contractile cells begin to perform spontaneous contractions, pushing peristaltic waves of interbronchial fluid to the periphery. These movements, too, stimulate branched morphogenesis and prevent uncontrolled airway expansion as lung fluid is secreted into the lung (Schittny et al. 2000; Sparrow et al. 1994).

The canalicular stage occurs between 16-26 gestational weeks and comprises the differentiation of the epithelium that allows the morphological distinction between the airways (acino / ventilatory unit) (Winkelmann and Noack 2010).

At the junction of the bronchialveolar duct (BADJ), there is an abrupt change in the epithelium from hair cells and from Clear cells to type I and type II alveolar epithelial cells (Winkelmann and Noack 2010). This junction is formed at the canalicular stage, when epithelial differentiation occurs and is of particular importance, because it represents a niche of stem cells (McQualter et al. 2010). It has recently been shown that the junction bronchialveolar remains constant throughout the lung development in the generation of the airways, where it was originally formed (Barre et al. 2014, 2016).

The saccular stage occurs between 24-38 gestational weeks and represents an intermediate stage, when the branching morphogenesis ceases and the alveolarization has not yet started (Cardoso and Lu
2006; Morrisey et al. 2013). they are coated by type 1 and type 2 cells (Cardoso; 2006; Rock and Hogan, 2011).

At the end of the saccular stage, the mesenchyme located between the future airways contains a loose three-dimensional vascular network in proliferation, due to intense angiogenesis, conferring a high capillary density. The future airways that will become alveolar ducts grow in width and length, change shape and appear as "canaliculi", which form the canalization of the mesenchyma through the airways and capillaries. The growth of the airways and apoptosis cause condensation of the mesenchyme., where the volume and the total number of mesenchymal cells decrease (Rogelj et al. 1989).

In parallel with alveolarization, the double layer capillary network of immature septa merges with a single layer network, resulting in an optimized configuration for gas exchange. Alveolarization still continues, because, in places where new septa are shedding pre-existing mature septa, the second necessary capillary layer will be formed instantly by angiogenesis, confirming a lifelong alveolarization capacity, which is important for any type of lung regeneration.

The lung mesoderm represents a source of essential paracrine instructional signals that regulate the proliferation and differentiation of the endoderm progenitor and also contributes to the various lung structures, including airway smooth muscle, vascular smooth muscle, endothelial cells, mesothelial cells and many less known mesodermal strains, such as pericytes, alveolar fibroblasts and lipofibroblasts. The lung mesoderm is believed to originate from the initial mesoderm that surrounds the ventral anterior intestine.

\section{il. Pulmonary Cell Types}

\section{a) Embryonic Lung Cells}

The embryonic pulmonary epithelium differentiates into hair, serous secretory cells, goblet cells, clear cells, basal cells and neuroendocrine (NE) cells. The proportions of these cells vary along the proximal-distal axis. In bronchioles, clear cells are more abundant than the ciliated ones, with some groupings of NE cells, called neuroepithelial bodies or NEBs. Goblet cells are marked by the expression of the transcription factor SPDEF and mucin-5ac (Muc5ac). (Morrisey and Hoghan, 2010).

Neuroendocrine (NE) cells are the first epithelial cells to appear in the lung and are more abundant in fetal and neonatal lungs than in the adult lung. basic ID2 helix loop. These multipotent cells have the ability to give rise to all major types of respiratory epithelial cells, including PNECs (pulmonary neuroendocrine cells) (Rawlins et al 2009). 
The evidence suggests that the specification of the fate of PNECs is controlled by interference between $\mathrm{bH} H \mathrm{H}$ activating and repressing genes, a conserved mechanism between Drosophila and mammals (Ito et al 2006).

The ASCL1 complex activates NE differentiation, while the HES 1 gene suppresses this pathway, inhibiting the formation of the ASCL1 / TCF3 complex.

Notch signaling was also important in specifying the PNEC lineage. The delta-like Notch ligand 1 (DLL1) is expressed in NE cells in the proximal airways. Its activity may be under the control of ASCL1.Notch 2 mediates the fate of clear hair cells.

Finally, the migration control program for normal pulmonary neuroendocrine cells and malignant cells is extremely relevant for the understanding and treatment of metastasis of small cell lung cancer. Recently, a new form of epithelial cell migration shown by normal pulmonary neuroendocrine cells during pulmonary epithelial development has been demonstrated, called 'sliding', which is used to organize neuroendocrine cells into stereotyped groups (Kou 2015). The normal sliding program involves the transient activation of an epithelialmesenchymal transition (EMT), in which the pulmonary neuroendocrine cells migrate over and around other epithelial cells to meet, without ever invading the lung mesenchyma. The pulmonary NE cells are distributed throughout the bronchial epithelium, interspersed between secretory cells (Claras) and hair cells, the two main types of airway epithelial cells (Rock and Hogan, 2011; Semenova 2015). The clusters of NE or (NEBs) are highly innervated (Brouns et al., 2008) and have sensory and neurosecretory functions; stem cell function, which helps to replace the bronchial epithelium after severe injury (Guha et al., 2012; Reynolds et al., 2000; Song et al., 2012); and function of small cell lung cancer cell initiator (Song et al., 2012; Kuo 2015).

Further investigation into the sliding program is likely to reveal molecular dependencies directed at small cell carcinoma to attenuate or perhaps even prevent metastasis to extrapulmonary organs, which is the main cause of patient death (Semenova 2015; Kuo, 2015)

\section{ili. Pulmonary Cells of Adults}

Pulmonary epithelial cells are largely subdivided into airways (tracheal / bronchiolar) and alveolar types. The tracheobronchial airways are lined with pseudostratified epithelium in which each cell comes into contact with the basement membrane. Below the basement membrane are blood and lymph vessels, smooth muscle, cartilage, fibroblasts and nerves (Hogan et al., 2014). The most distal intrapulmonary conduction airways are lined by simple columnar epithelium. The gas exchange is performed inside the alveolar epithelium.
PNECs represent only $0.4 \%$ of adult epithelial cells and have endocrine and neuronal cell properties. They express neural markers, such as NCAM1 and ASCL1 neural cell adhesion molecules (Chanda et al. 2014). They are associated with intraepithelial nerve fibers and can transmit signals to the central nervous system. Generally, it contains electron-dense vesicles, which accumulate peptides, related to the bombesin and calcitonin gene (CGRP), which acts as a vasodilator; and to the amines, represented by serotonin, which act as a vasoconstrictor. The functions of PNECs include control of airway tone, pulmonary blood flow and immunomodulation.

Brush cells make up less than $1 \%$ of the airway epithelium and have recently been shown to have a chemosensory role that can allow the detection of bacterial infections (Tizzano et al., 2011). Basal cells are stem cells that self-renew and differentiate into secretory and hair cells during homeostasis and repair (Teixeira et al., 2013; Watson et al., 2015). Secretory cells are predominantly of the mucous subtype. It is not clear whether mucus-secreting cells retain the ability to proliferate and function as stem / progenitor cells (Teixeira et al., 2013).

The alveolar epithelium consists of type I and type II alveolar cells (AT1 and AT2 cells) that are surrounded by capillaries and fibroblasts (Weibel, 2015). AT1 cells are flat, highly extended and specialized for gas exchange. AT2 cells are cuboidal, more common and specialized in the production of surfactant, a complex mixture of proteins and phospholipids that reduces surface tension in the alveolar region (Crapo et al., 1982; Hogan et al., 2014; Weibel, 2015; Williams, 2003). AT2 cells are the main alveolar epithelial stem cells and can self-renew and differentiate into AT1 cells (Barkauskas et al., 2013; Desai et al., 2014; Rock et al., 2011).

Traditionally, alveolar fibroblasts have been characterized mainly as myofibroblasts and lipofibroblasts, but their exact roles have not yet been defined and there are controversies about the existence of lipofibroblasts in human lungs. (Bhattacharya and Westphalen, 2016).

The lung also contains a resident population of immune cells and alveolar macrophages, which play important roles in surfactant homeostasis and innate immunity (Bhattacharya and Westphalen, 2016).

\section{Molecular Regulation in EMBRYOGENESIS}

The first indication of the respiratory precursor in the endoderm of the primitive intestinal tube is registered by the expression of TTF1 (Thyroid Transcriptional factor 1, homeobox or NKx2.1 type transcription factor) where the thyroid and lungs will be formed (Cardoso and Lu 2006). 
CK8 / CK18 cytokeratins are the first keratins to appear in embryogenesis, already in pre-implantation embryos and also appear to be the oldest keratins during phylogenesis (Jackson, 1980; Blumenberg 1988). With respect to malignant tumors, K8 and K18 flush strongly the majority of adenocarcinomas, hepatocellular carcinomas, renal cell carcinomas and neuroendocrine carcinomas. These keratins can be useful in diagnostic immunohistochemistry in cases of carcinomas with low keratin content, such as small cell lung cancer, to prove their epithelial nature (Moll, 2008). P63 plays a prominent role in controlling the functions of epithelial stem cells and in differentiating and stratifying tissue derived from ectoderm during embryonic development. (Guerrini, 2011)

The transcription factor Sox2 marks proximal epithelial progenitors and Sox9 marks distal epithelial progenitors. Additional markers of Sox9 positive distal progenitor cells include surfactant proteins, such as surfactant protein C (Sftpc), the transcription factor Id2. Lineage screening studies have suggested that positive distal Id2 cells can generate distal and proximal cell lines. This capacity for multipotent differentiation is subsequently lost, and positive Id2 progenitor cells may form only distal alveolar epithelia (Rawlins 2018).

All early events in lung development are controlled by a variety of signaling pathways, including Fgf, Tgfb, Wht, SOX, Hedgehog (Shh-Sonic hedgehog, its Patched 1 receptor and transcription factors like Gli13), Notch and acid retinoic (Rock and Hogan 2011; Katton and Morrisey 2014).

The process also depends on a complex regulation by signaling pathways that includes members of the TgfB (Transforming Growth Factor Beta) and Wnt (Wingless-type) family, Bmp4 (Bone Morphogenetic Protein 4, of the Tgf Beta family). Notch signaling plays an important role in controlling cell differentiation (Tsao 2011).

On the tenth day of the embryonic period, mesenchymal cells begin to express abundant vascular endothelial growth factor (VEGF) (White et al., 2007), which is an important ligand for the VEGF 2 receptor (VEGFR2) in vasculogenesis and angiogenesis (Chung and Ferrara, 2011; Karaman et al., 2018; Apte et al., 2019). VEGF expression stimulates the alveolar capillary network. FGF10 derived from the mesenchyme also stimulates mTORC1 / Spry2 epithelial signaling, and this signaling triggers the production of VEGF in the epithelium (Scott et al., 2010).

Columnar, non-ciliated epithelial cells are identified by the expression of the product CC10 (Clara Cell Secretory Prootein 10KD) (Reynolds 2002).

Interleukins, IL4 and IL13, Foxa2 and Spdef transcription factors (Sam pointed Domain-containing etc. Transcription Factor) influence the differentiation of goblet cells (Chen 2009) that develop only in the postnatal period (Pack 1980) and are evaluated by the expression of Muc5ac (Main Mucina Constituent of mucus) and Spdef.

The transcription factor called Foxj1 (Forklvad

Box Trancription Factor) identifies respiratory progenitors that will give rise to hair cells (Rawlins 2007).

NE cells are identified using ACCGRP (Calcitonin Gene Related Peptide) and PGP9.5 (Protein Gene Product 9.5). Mash 1 9Achaete-Scute-ComplexILike1) is a transcription factor of the basic helix-loophelix family) that is fundamental in the formation of this cell type (Guilhemont 1993).

Basal cells are identified by the expression of specific molecular markers Trp-63 (Transcription Factor Transformation-related Protein or P63), cytokeratin 14 (Krt14) and cytokeratin 5 (Krt5) (School 2004)

Evidence indicates that basal cells comprise a population of multipotent parents (Rowlins and Hogan 2006).

Antigens such as ICAM-I (Intercellular Adhesion Molecule) are abundantly expressed by type I pneumocytes and by expression of Type I Caveolins (Transmembrane Proteins).Type II pneumocytes express proteins associated with pulmonary surfactants, such as SP-A, SP-B, SP-C and SP-D (Costa 2001). Transcription factors such as cat-6, TTF1, Hnf3 / 3, C / ebpa, hormones glucocorticoids and Fgfs are involved in the differentiation of pneumocyte II (Cardoso 1997).

With aging, human lung functions decrease at a rate of $1 \%$ per year after the age of 25 , even without lung diseases (Janssens et al., 1999; Sharma and Goodwin, 2006). The lung starts to exhibit several changes, including increased secretion of pro-inflammatory cytokines, attenuated immune response and changes in the structural proteins of the extracellular membrane (Meiners et al., 2015; Navarro and Driscoll, 2017). Structural changes occur, such as spaces increased air space, loss of surface area and decreased static elastic recoil, with the most significant decline in the number and functions of capillary endothelial cells (Thurlbeck and Angus, 1975).

Fases do desenvolvimento pulmonary e mediadores

\section{Epigenetic Regulators of Fate and DifFerentiation of Pulmonary Epithelial Cells}

Recent studies have also identified epigenetic mechanisms of histone changes in the control of lung development. Acetylation through Histone acetyltransferase (HATs) promotes genetic transcription, and deacetylated histone (HDACs) removes the acetyl group, leading to genetic silencing (Choudhary et al., 2009). There is evidence that HATs are necessary for embryonic lung development. The loss of Hdac in the pulmonary epithelium results in reduced expression of Sox2, preventing the development of multiple types of proximal cells (Wang et al., 2013). This change in Sox2 
expression is, in part, mediated by increased expression of Bmp4, which also contributes to the severe branching defects seen in Hdac mutants. It has also been shown that hyperoxia during neonatal development results in decreased hdac activity, leading to alveolar hyperplasia and interrupted alveolarization (Zhu et al., 2012).

Although histone acetylation is known to play an important role in the lung, little is known about the roles of other epigenetic complexes during lung development. The methyltransferases Suv39H1 and Suv39H2, which induce transcriptional silencing through histone $\mathrm{H} 3$ lysine 9 methylation, directly repress the expression of the surfactant protein SP-A (Sftpa1) during hypoxia (Benlhabib and Mendelson, 2011). Suv39H1 and Suv39H2 are also highly expressed in early lung development, suggesting that they may inhibit SP-A transcription until later in development. During pulmonary fibrosis, DNA methylation by Dnmt1 represses the transcription of miR17 92, a microRNA cluster that regulates lung development (Dakhlallah et al., 2013). Likewise, Dnmt1 mediates the progression of lung cancer through the methylation of several promoter regions (Dakhlallah et al., 2013).

\section{Conclusion}

Recent studies demonstrate that cell signaling and gene expression pathways, including PTEN, protein kinase C (iota), Wnt, hedgehog, c-kit, Akt and others that can play important roles in the transformation of endogenous progenitor cells into cancer cells lung.

Pluripotent stem cells (PSCs) can be derived from the internal cell mass of the initial embryo (in the case of embryonic stem cells, ESCs) or can be reprogrammed from fully differentiated cells (in the case of iPSCs). They retain the potential to differentiate into any type of cell in the body. For this reason, we can say that our organoid system provides a genetically treatable tool and, therefore, specific human characteristics of lung development should be investigated investigated. (Nicolic 2017).

Disclosure Statement

The authors declare no conflict of interest

\section{References Références Referencias}

1. Apte, R. S., Chen, D. S., and Ferrara, N. VEGF in signaling and disease: beyond discovery and development. Cell 176, 2019, 1248-1264. doi: 10.1016/j.cell.2019.01.02

2. Bhattacharya, J. and Westphalen, K. Macrophageepithelial interactions in pulmonary alveoli. Semin. Immunopathol.2016, 38, 461-469. doi:10.1007/s 00281-016-0569-x.

3. Bhattacharya, S., Go, D., Krenitsky, D. L., Huyck, H. L., Solleti, S. K., Lunger, V. A., Metlay, L., Srisuma, S., Wert, S. E., Mariani, T. J. et al. Genome-wide transcriptional profiling reveals connective tissue mast cell accumulation in bronchopulmonary dysplasia. Am. J. Respir. Crit. Care Med.2012. 186, 349-358. doi:10.1164/rccm.201203-0406OC.

4. Barkauskas C. E., Cronce M. J., Rackley C. R., Bowie E. J., Keene D. R., Stripp B. R., Randell S. H., Noble P. W., Hogan B. L. Type 2 alveolar cells are stem cells in adult lung. J. Clin. Invest. 2013,123, 3025-3036.

5. Barre SF, Haberthur D, Stampanoni M, Schittny JC. Efficient estimation of the total number of acini in adult rat lung. Physiol Rep. 2014;2 doi: 10.14814/phy2.12063.

6. Benlhabib H., Mendelson C. R.Epigenetic regulation of surfactant protein A gene (SP-A) expression in fetal lung reveals a critical role for Suv39h methyltransferases during development and hypoxia. Mol. Cell. Biol. 31, 20111949-1958.

7. Blumenberg M. Concerted gene duplications in the two keratin gene families. J Mol Evol .1998, 27(3):203-211.

8. Koos BJ, Rajaee A. Fetal breathing movements and changes at birth. Adv Exp Med Biol. 2014; 814:89101. doi: 10.1007/978-1-4939-1031-1 8 .

9. Cardoso WV. Molecular regulation of lung development. Annu Rev Physiol. 2001;63:471-494

10. Cardoso W. V. and Lu J. (2006). Regulation of early lung morphogenesis: questions, f-Carla $F$ Bender Kim, Erica L Jackson, Amber E Woolfenden, Sharon Lawrence, Imran Babar, Sinae Vogel, Denise Crowley, Roderick T Bronson, Tyler Jacks. Identification of bronchioalveolar stem cells in normal lung and lung. cancerCell. 2005 Jun 17;121(6):823-35;

11. Carla $F$ Bender Kim, Erica $L$ Jackson, Amber $E$ Woolfenden, Sharon Lawrence, Imran Babar, Sinae Vogel, Denise Crowley, Roderick T Bronson, Tyler Jacks. Identification of bronchioalveolar stem cells in normal lung and lung cancer Cell. 2005 Jun 17;121(6):823-35;

12. Chanda D, Otoupalova E, Smith SR, Volckaert T, De Langhe SP, Thannickal VJ. Developmental pathways in the pathogenesis of lung fibrosis. Mol Aspects Med. 2019; 65:56-69. doi:10.1016/ j.mam.2018.08.004

13. Chung, A. S., and Ferrara, N. Developmental and pathological angiogenesis. Annu. Rev. Cell Dev. Biol. 22011, 27, 563-584. doi: 10.1146/annurevcellbio-092910-154002

14. Choudhary SS, Choudhary SR. Sleep effects on breathing and respiratory diseases. Lung India. 2009 Oct; 26(4):117-22. doi: 10.4103/09702113.56345. PMID: 20531993; PMCID: PMC2876696.

15. Costa RH, Kalinichenko VV, Lim L. Transcription factors in mouse lung development and function. Am J Physiol Lung Cell Mol Physiol. 2001;280:L823L838. 
16. Coulombe, P., Paliouras, G. N., Clayton, A., Hussainkhel, A., Fuller, M., Jovanovic, V., et al. (2019). Endothelial Sash1 is required for lung maturation through nitric oxide signaling. Cell Rep. 27, 1769-1780.e4. doi: 10.1016/j.celrep.2019.04.03.

17. Crapo JD. Morphologic changes in pulmonary oxygen toxicity. Annu Rev Physiol. 1986;48:721-73

18. Dakhlallah D., Batte K., Wang Y., Cantemir-Stone C. Z., Yan P., Nuovo G., Mikhail A., Hitchcock C. L., Wright V. P., Nana-Sinkam S. P., et al. The epigenetic regulation of miR-1792 contributes to the pathogenesis of pulmonary fibrosis. Breathe. Care Med.2013, 187, 397-405.

19. Desai TJ, Brownfield DG, Krasnow MA. Alveolar progenitor and stem cells in lung development, renewaand cancer. Nature. 2014; 507:190-194. doi: 10.1038/nature12930.

20. Ding BS, Nolan DJ, Guo P, Babazadeh AO, Cao Z, Rosenwaks Z, Crystal RG, Simons M, Sato TN, Worgall S, Shido K, Rabbany SY, Rafii S. Endothelial-derived angiocrine signals induce and sustain regenerative lung alveolarization. Cell. 2011 Oct 28; 147(3):539-53. doi: 10.1016/j.cell. 2011.10.003.

21. Eramo A, Lotti F, Sette G, Pilozzi E, Biffoni M, Di Virgilio A, Conticello C, Ruco L, Peschle C, De Maria $\mathrm{R}$. Identification and expansion of the tumorigenic lung cancer stem cell population. Cell Death Differ. 2008 Mar; 15(3): 504-14. doi: 10.1038/sj.cdd. 4402283. Epub 2007 Nov 30. PMID: 18049477

22. Guerrini R, Oguni H. Borderline Dravet syndrome: a useful diagnostic category? Epilepsia. 2011 Apr;52 Suppl 2:10-2. doi: 10.1111/j.1528-1167.2011. 02995.x. PMID: 21463273.

23. Guha, A., Vasconcelos, M., Cai, Y., Yoneda, M., Hinds, A., Qian, J., Li, G., Dickel, L., Johnson, J. E., Kimura, S., Guo, J., McMahon, J., McMahon, A. P., \& Cardoso, W. V. (2012). Neuroepithelial body microenvironment is a niche for a distinct subset of Clara-like precursors in the developing airways. Proceedings of the National Academy of Sciences of the United States of America, 109(31), 12592-12597. https://doi.org/10.1073/pnas.1204710109.

24. Hines, E.A., and Sun, X. Tissue crosstalk in lung development. J. Cell. Biochem.2014, 115, 14691477.

25. Hogan B. L. M., Barkauskas C. E., Chapman H. A., Epstein J. A., Jain R., Hsia C. C. W., Niklason L., Calle E., Le A., Randell S. H. et al. Repair and regeneration of the respiratory system: complexity, plasticity, and mechanisms of lung stem cell function. Cell Stem Cell.2014, 15, 123-138.

26. Hong K.U.Reynolds S.D.Giangreco A.Hurley C.M.Stripp B.R.Clara cell secretory proteinexpressing cells of the airway neuroepithelial body microenvironment include a label-retaining subset and are critical for epithelial renewal after progenitor cell depletion.Am. J. Respir. Cell Mol. Biol. 2001; 24: 671-68.

27. Hong K. U., Reynolds S. D., Giangreco A., Hurley C. M. and Stripp B. R. Clara cell secretory proteinexpressing cells of the airway neuroepithelial body microenvironment include a label-retaining subset and are critical for epithelial renewal after progenitor cell depletion. Am. J. Respir. Cell Mol. Biol.2001, 24, 671-681. 10.1165/ajrcmb.24.6.4498.

28. Hong K. U., Reynolds S. D., Watkins S., Fuchs E. and Stripp B. R.Basal cells are a multipotent progenitor capable of renewing the bronchial epithelium. Am. J. Pathol.2004 164, 577-588.

29. Ho M.M,, et al.Population in Human Lung Cancer Cell Lines and Tumors Is Enriched with Stem-like Cancer Cells.Cancer Res May 152007 (67) (10) 4827-4833; DOI: 10.1158/0008-5472.CAN-063557oi:10.1016/j.stem.2014.07.012.

30. Ito, K., and Barnes, P. J. COPD as a disease of accelerated lung aging. Chest 2009,135, 173-180. doi: 10.1378/chest.08-1419.

31. Jackson SR, Lee J, Reddy R, Williams GN, Kikuchi A, Freiberg $Y$, Warburton D, Driscoll B: Partial pneumonectomy of telomerase null mice carrying shortened telomeres initiates cell growth arrest resulting in a limited compensatory growth response. Am J Physiol Lung Cell Mol Physiol 2011;300:L898-L909.

32. Janssens JP, Pache JC, Nicod LP: Physiological changes in respiratory function associated with ageing. Eur Respir J 1999;13:197-205.

33. Karaman, S., Leppanen, V. M., and Alitalo, K. (2018). Vascular endothelial growth factor signaling in development and disease. Development 145: dev151019. doi: 10.1242/dev.151019.

34. Kim CF, Jackson EL, Woolfenden AE, Lawrence S, Babar I, Vogel S, Crowley D, Bronson RT, Jacks T. Identification of bronchioalveolar stem cells in normal lung and lung cancer. Cell. 2005; 121:823835.

35. Koos BJ, Rajaee A. Fetal breathing movements and changes at birth. Adv Exp Med Biol. 2014; 814:89101. doi: 10.1007/978-1-4939-1031-18.

36. Kobayashi $Y$, Sakao $Y$, Deshpande GA, et al. The association between baseline clinical-radiological characteristics and growth of pulmonary nodules with ground-glass opacity. Lung Cancer 2014; 83:61-6.

37. Kosaka $\mathrm{T}$, Yatabe $\mathrm{Y}$, Endoh $\mathrm{H}$, et al. Analysis of epidermal growth factor receptor gene mutation in patients with non-small cell lung cancer and acquired resistance to gefitinib. Clin Cancer Res 2006; 12:5764-9.

38. Kotton, D. N., and Morrisey, E. E. Lung regeneration: mechanisms, applications and emerging stem cell populations. Nat. Med.2014, 20, 822-832. doi: 10.1038/nm.3642. 
39. Kuo CS, Krasnow MA. Formação de um órgão neurossensorial por deslizamento de células epiteliais. Célula. 2015; 163: 394-405.

40. Zhang Y, Goss AM, Cohen ED, Kadzik R, Lepore JJ, Muthukumaraswamy K, Yang J, DeMayo FJ, Whitsett JA, Parmacek MS, Morrisey EE. A Gata6Wht pathway required for epithelial stem cell development and airway regeneration. Nature Genetics. 2008; 40:862-87.

41. Li C., Xiao J., Hormi K., Borok Z. and Minoo P. Wnt5a participates in distal lung morphogenesis. Dev. Biol. 2020,248, 68-81. 10.1006/dbio.2002.0729

42. Li C., Hu L., Xiao J., Chen H., Li J. T., Bellusci S., Delanghe S. and Minoo P. Wnt5a regulates Shh and Fgf10 signaling during lung development. Dev. Biol.2005, 287, 86-97. 10.1016/j.ydbio.2005.08.035

43. Li J., Wang Z., Chu Q., Jiang K., Li J. and Tang N. (2018). The strength of mechanical forces determines the differentiation of alveolar epithelial cells. Dev. Cell 44, 297-312.e5. 10.1016/j.devcel. 2018.01.008]

44. Li R., Herriges J. C., Chen L., Mecham R. P. and Sun X. FGF receptors control alveolar elastogenesis. Development.2017, 144, 4563-4572. 10.1242/dev.149443

45. Liu X., Driskell R. R. and Engelhardt J. F. Airway glandular development and stem cells. Curr. Top. Dev. Biol.2004, 64, 33-56. 10.1016/S0070-2153 (04)64003-8.

46. Liu X., Li W., Fu X. and Xu Y. The immunogenicity and immune tolerance of pluripotent stem cell derivatives. Front Immunol .2017;8, 645 10.3389/fimmu.2017.0064.

47. McQualter JL, Yuen K, Williams B, Bertoncello I. Evidence of an epithelial stem/progenitor cell hierarchy in the adult mouse lung. Proc Natl Acad Sci U S A. 2010; 107:1414-1419. doi: 10.1073/ pnas.0909207107.

48. Mendelson C. R., Gao E., Young P. P., Michael L. F. and Alcorn J. L. Transcriptional regulation of the surfactant protein-A gene in fetal lung. Chest .1997; 111, 96S-104S. 10.1378/chest.111.6_Supplement. 96S-

49. Moll R, Divo M, Langbein L. The human keratins: biology and pathology. Histochem Cell Biol. 2008; 129(6):705-733. doi:10.1007/s00418-008-0435-6

50. Morrisey E. E. and Hogan B. L. M. Preparing for the first breath: genetic and cellular mechanisms in lung development. Dev. Cel.2010; | 18, 8-23. 10.1016/ j.devcel.2009.12.010

51. Morrisey EE, Cardoso WV, Lane RH, Rabinovitch M, Abman SH, Ai X, Albertine KH, Bland RD, Chapman HA, Checkley W, Epstein JA, Kintner CR, Kumar M, Minoo P, Mariani TJ, McDonald DM, Mukouyama YS, Prince LS, Reese J, Rossant J, Shi W, Sun X, Werb Z, Whitsett JA, Gail D, Blaisdell CJ, Lin QS
Molecular determinants of lung development. Ann Am Thorac Soc.2013; 10:S12-S1.

52. Navarro S, Driscoll B. Regeneration of the Aging Lung: A Mini-Review. Gerontology. 2017; 63(3):270280. doi: 10.1159/000451081. Epub 2016 Nov 9. PMID: 27825158.

53. Nikolic, M.Z., Sun, D., and Rawlins, E.L. Human lung development: recent progress and new challenges. Development.2018; 145, 145.

54. Pan J, Copland I, Post M, Yeger H, Cutz E. Mechanical stretch-induced serotonin release from pulmonary neuroendocrine cells: implications for lung development. Am J Physiol Lung Cell Mol Physiol. 2006 Jan; 290(1): L185-93. doi: 10.1152/ajplung.00167.

55. Parera, M. C., van Dooren, M., van Kempen, M., de Krijger, R., Grosveld, F., Tibboel, D., et al. Distal angiogenesis: a new concept for lung vascular morphogenesis. Am. J. Physiol. Lung Cell. Mol. Physiol.2005; 288, L141-L149. doi: 10.1152/ ajplung.00148.2004.

56. Park, J. E., Keller, G. A., and Ferrara, N. The vascular endothelial growth factor (VEGF) isoforms, differential deposition into the subepithelial extracellular matrix and bioactivity of extracellular matrix-bound VEGF. Mol. Biol. Cell.1993; 4, 13171326. doi: $10.1091 / \mathrm{mbc} .4 .12 .1317$.

57. Park, W. Y., Miranda, B., Lebeche, D., Hashimoto, G., and Cardoso, W. V. FGF-10 is a chemotactic factor for distal epithelial buds during lung development. Dev. Biol. 1998; 201, 125-134. doi: 10.1006/dbio.1998.8994.

58. Rawlins E. L., Ostrowski L. E., Randell S. H. and Hogan B. L. M. Lung development and repair: contribution of the ciliated lineage. Proc. Natl. Acad. Sci. USA2007; 104, 410-417. 10.1073/pnas. 0610770104.

59. Rawlins E. L., Clark C. P., Xue Y. and Hogan B. L. $M$. The Id2+ distal tip lung epithelium contains individual multipotent embryonic progenitor cells. Development.2009a; 136, 3741-3745. 10.1242/ dev.037317.

60. Rawlins E. L., Okubo T., Xue Y., Brass D. M., Auten R. L., Hasegawa H., Wang F. and Hogan B. L. M. The role of Scgb1a1 + Clara cells in the long-term maintenance and repair of lung airway, but not alveolar, epithelium. Cell Stem Cell.2009b; 4, 525534. 10.1016/j.stem.2009.04.002.

61. Rehan V. K., Sugano S., Wang Y., Santos J., Romero S., Dasgupta C., Keane M. P., Stahlman M. T. and Torday J. S. Evidence for the presence of lipofibroblasts in human lung. Exp. Lung Res.2006; 32, 379-393. 10.1080/01902140600880257.

62. Reynolds S. D., Giangreco A., Power J. H. and Stripp B. R. Neuroepithelial bodies of pulmonary airways serve as a reservoir of progenitor cells capable of epithelial regeneration. Am. J. 
Pathol.2000; 156, 269-278. 10.1016/S0002-9440 (10)64727-X.

63. Reynolds S. D., Reynolds P. R., Pryhuber G. S., Finder J. D. and Stripp B. R. Secretoglobins SCGB3A1 and SCGB3A2 define secretory cell subsets in mouse and human airways. Am. J. Respir. Crit. Care Med.2002; 166, 1498-1509. 10.1164/rccm.200204-2850C.

64. Rock J. R., Onaitis M. W., Rawlins E. L., Lu Y., Clark C. P., Xue Y., Randell S. H. and Hogan B. L. M. Basal cells as stem cells of the mouse trachea and human airway epithelium. Proc. Natl. Acad. Sci. USA.2009; 106, 12771-12775. 10.1073/pnas. 090685010.

65. Rogelj S, Klagsbrun M, Atzmon R, Kurokawa M, Haimovitz A, Fuks Z, Vlodavsky I Basic fibroblast growth-factor is an extracellular-matrix component required for supporting the proliferation of vascular endothelial-cells and the differentiation of Pc12 cells. J Cell Biol.1989; 109:823-831.

66. Scott, C. L., Walker, D. J., Cwiklinski, E., Tait, C., Tee, A. R., and Land, S. C. Control of HIF-1\{alpha\} and vascular signaling in fetal lung involves cross talk between mTORC1 and the FGF-10/ FGFR2b/Spry2 airway branching periodicity clock. Am. J. Physiol. Lung Cell. Mol. Physiol.2010; 299, L455-L471. doi: 10.1152/ajplung.00348.2009.

67. Sharma, G., and Goodwin, J. Effect of aging on respiratory system physiology and immunology. Clin. Interv. Aging.2006; 1, 253-260. doi: 10.2147/ciia.2006.1.3.25.

68. Schittny J. C. Development of the lung. Cell Tissue Res. 2017; 367, 427-444. 10.1007/s00441-016-254.

69. Schittny JC, Burri PH (2004) Morphogenesis of the mammalian lung: aspects of structure and extracellular matrix components. In: Massaro D, Massaro GD, Chambon P (eds) Lung development and regeneration. Marcel Dekker, New York, pp 275-31.

70. Schittny JC, Burri PH (2008) Development and growth of the lung. In: Fishman AP, Elias JA, Fishman JA, Grippi MA, Kaiser LR, Senior RM (eds) Fishman's pulmonary diseases and disorders, vol 1. McGraw-Hill, New-York, pp 91-114.

71. Rock JR, et al. Múltiplas populações estromais contribuem para a fibrose pulmonar sem evidências de transição epitelial para mesenquimal. Proc Natl Acad Sci US A. 2011; 108: E1475-1483. doi: 10.1073 / pnas. 1117988108.

72. Semenova EA, Nagel R, Berns A. Origins, paisagem genética e terapias emergentes de câncer de pulmão de pequenas células. Genes Dev. 2015; 29: 1447-1462.

73. Teixeira, V. H., Nadarajan, P., Graham, T. A., Pipinikas, C. P., Brown, J. M., Falzon, M., Nye, E., Poulsom, R., Lawrence, D., Wright, N. A. et alStochastic homeostasis in human airway epithelium is achieved by neutral competition of basal cell progenitors.2013; Elife 2, e00966. doi:10.7554/eLife.00966.

74. Tizzano, M., Cristofoletti, M., Sbarbati, A. and Finger, T. E. Expression of taste receptors in solitary chemosensory cells of rodent airways. BMC Pulm. Med.2011; 11, 3. doi:10.1186/1471-2466-11-3.

75. Watson, J. K., Rulands, S., Wilkinson, A. C., Wuidart, A., Ousset, M., Van Keymeulen, A., Göttgens, B., Blanpain, C., Simons, B. D. and Rawlins, E. L. Clonal dynamics reveal two distinct populations of basal cells in slow-turnover airway epithelium. Cell Rep. 2015; 12, 90-101. doi:10.1016/j.celrep.2015. 06.01.

76. Wang Y., Huang C., Reddy Chintagari N., Bhaskaran M., Weng T., Guo Y., Xiao X., Liu L. (2013b). miR-375 regulates rat alveolar epithelial cell trans-differentiation by inhibiting $\mathrm{Wnt} / \beta$-catenin pathway. Nucleic Acids Res. 41, 3833-3844.

77. Wang Y., Tian Y., Morley M. P., Lu M. M., Demayo F. J., Olson E. N., Morrisey E. E. (2013c). Development and regeneration of Sox2+ endoderm progenitors are regulated by a Hdac1/2-Bmp4/Rb1 regulatory pathway. Dev. Cell 24, 345-358.

78. Williams A. E., Moschos S. A., Perry M. M., Barnes P. J., Lindsay M. AMaternally imprinted microRNAs are differentially expressed during mouse and human lung development. Dev. Dyn. 2007; 236, 572-580.

79. Winkelmann A, Noack $T$ The Clara cell: a "Third Reich eponym"? Eur Respir J.2010; 36:722-727.

80. Woods JC, Schittny JC (2016) Lung structure at preterm and term birth. In: Jobe $\mathrm{AH}$, Whitsett JA, Abman SH (eds) Fetal lung development - clinical correlates \& future technologies. Cambridge University Press, New York, pp 126-140.

81. Weibel ER: On the tricks alveolar epithelial cells play to make a good lung. Am J Respir Crit Care Med 2015; 191:504-513.

82. White, A. C., Lavine, K. J., and Ornitz, D. M. FGF9 and $\mathrm{SHH}$ regulate mesenchymal Vegfa expression and development of the pulmonary capillary network. Development. 2007; 134, 3743-3752. doi: 10.1242/dev.004879.

83. Yin Z., Gonzales L., Kolla V., Rath N., Zhang Y., Lu M.M., Kimura S., Ballard P. L., Beers M. F., Epstein J. A., et al. The hop works downstream of Nkx2.1 and GATA6 to mediate the HDAC-dependent negative regulation of lung gene expression. Am. J. Physiol. Pulmonary cell Mol. Physiol.2006; 291, L191-L199.

84. Zacharias W. J., Frank D. B., Zepp J. A., Morley M. P., Alkhaleel F. A., Kong J., Zhou S., Cantu E. and Morrisey E. E. Regeneration of the lung alveolus by an evolutionarily conserved epithelial progenitor. Nature.2018; 555, 251-255. 0.1038/nature2578. 
85. Zhu L., Li H., Tang J., Zhu J., Zhang Y. Hyperoxia arrests alveolar development through suppression of histone deacetylases in neonatal rats. Pediatr. Pulmonol. 2012; 47, 264-274. 